\title{
Phylogenetic study of the endemic species Oxytropis almaatensis (Fabaceae) based on nuclear ribosomal DNA ITS sequences
}

\author{
Shyryn Almerekova ${ }^{1,2}$, Nashtay Mukhitdinov² and Saule Abugalieva ${ }^{1,2^{*}}$ \\ From 4th International Scientific Conference "Plant Genetics, Genomics, Bioinformatics and Biotechnology" (PlantGen 2017) \\ Almaty, Kazakhstan. 29 May - 2 June 2017
}

\begin{abstract}
Background: Oxytropis almaatensis Bajt. is a rare, narrow endemic species of the Trans-lli Alatau mountains in Kazakhstan. Up to now, no studies regarding the taxonomy and variation of key morphological traits of $O$. almaatensis were undertaken. The purpose of this analysis was to evaluate phenotypic variation of 0 . almaatensis and assess the position of the species within the genus based on nucleotide sequences of the nuclear ribosomal DNA internal transcribed spacer (ITS) region.

Results: Two populations of $O$. almaatensis were collected in neighboring gorges of the Trans-Ili Alatau Mountains. The ITS sequences from the samples of two populations of $O$. almaatensis were identical. The phylogenetic analysis indicated that $O$. almaatensis is within Oxytropis genetically close to 0 . glabra as these species formed a separate subclade. The phenotypic variation of populations was assessed using nine morphological traits and compared to descriptions of $O$. glabra. The range of variation for the traits between two populations was established. A clear morphological difference of 0 . almaatensis and O. glabra was found in peduncle length to leaf length ratio. This was in O. almaatensis 1.56, while in O. glabra, it was 1.0.

Conclusions: The study provides the first phenotypic description and phylogenetic placement of the rare endemic species 0 . almaatensis. The morphological traits in two O. almaatensis populations showed a high level of phenotypic variability. Although clearly different from O. glabra, the ITS phylogeny grouped these species in a subclade within the genus.
\end{abstract}

Keywords: Fabaceae, Oxytropis, Oxytropis almaatensis, Its, Phylogeny, Taxonomy

\section{Background}

The genus Oxytropis DC. is part of the Fabaceae family, and occurs with 450 species world-wide [1]. It is very diverse in Central Asian mountain regions [2]. The genus is part of the tribe Galegeae and traditionally grouped with Astragalus [3]. Oxytropis was originally considered as a part of Astragalus by Linnaeus, but was recognized as a distinct genus by De Candole (1802) who separated Oxytropis based on keel petal shape (pointed in Oxytropis vs.

\footnotetext{
* Correspondence: absaule@yahoo.com

${ }^{1}$ Institute of Plant Biology and Biotechnology, Almaty, Kazakhstan050040

2al-Farabi Kazakh National University, Department of Biodiversity and Bioresources, Almaty, Kazakhstan050040
}

obtuse in Astragalus) and pod septum shape (arising from adaxial suture in Oxytropis vs. abaxial in Astragalus) [4].

Oxytropis is one of the largest genera in the Central Asian flora [2]. Several studies based on molecular data reported that Oxytropis and Astragalus are sister groups [5, 6], and diverged approximately 12-16 Ma ago [7]. In the northern Tian-Shan, Oxytropis has been studied by Abdulina [8]. According to Abdulina [8], the distinguishing traits in Oxytropis are life form, stem development level, the level of the outgrowth of stipule with stem and each other, shape and structure of the beans, shapes and sizes of the corolla and calyx, and flower structure. Based on Malyshev's taxonomy [1], Oxytropis, in AsianRussia, consists of 6 subgenera and 25 sections. Hence, 
Oxytropis is one of the most complex and polymorphic genera in Fabaceae. Thus, there have been a number of studies to clarify the phylogenetic relationship among species of the genus. For instance, thirteen native Oxytropis species in Turkey were investigated to identify the phylogenetic relationships using the $\operatorname{trn} \mathrm{L}$ intron, trnL-F intergenic spacer, and $\operatorname{trn} \mathrm{V}$ intron of chloroplast (cp) DNA. Within the studied regions, the trnL intron was the most variable of the three regions studied [9]. In Asian Russia, several species from subgenera Oxytropis and Phacoxytropis of Oxytropis were studied utilizing the $\operatorname{trn} \mathrm{H}-p s b \mathrm{~A}$, $\operatorname{trn} \mathrm{L}-\operatorname{trn} \mathrm{F}$ and $\operatorname{trn} \mathrm{S}-\operatorname{trn} \mathrm{G}$ intergenic spacer regions of cpDNA [9]. Despite these reports and a number of other publications [10-13], a survey of scientific literature suggests that there is no universally accepted taxonomy for the genus [14]. Although general boundaries for subgenera and sections of the genus are broadly agreed among taxonomist from different continents, contradictory results in taxonomy can be explained by several factors: mis-identified samples, inaccurate sequencing, or different ploidy level of species within the genus [15].

Oxytropis is diverse and rich in endemism, and represented by 153 species in Central Asia [2]. In Kazakhstan, the genus comprises 119 species, 36 of which are endemic [16], and 10 are listed as endangered [17]. One of those endemic species, Oxytropis almaatensis Bajt., has been reported as a rare and narrowly endemic species growing in the Turgen Gorge of Trans-Ili Alatau mountains $[8,18,16]$ and potentially is an important medicinal plant [19]. There are several reports suggested that the species belongs to the section Eumorpha. Morphologically, the species is similar to O. glabra [18], except O. glabra belongs to section Mesogeae and has a tall stem, while $O$. almaatensis is a stemless plant.

Despite the richness and specificity of the flora of Kazakhstan, there are only few examples of the evaluation of wild plant species using genetic markers in this country, which includes the assessment of genetic variation in annual [20] and perennial species [21, 22]. The major focus of this study was the evaluation of morphological characters and assessment of taxonomic position of $O$. almaatensis based on the use of the nuclear ribosomal DNA internal transcribed spacer region (ITS) [23]. ITS is a highly polymorphic DNA marker and widely recognized as a valuable tool in plant evolutionary studies [24-26]. The research is part of the new nation-wide research project [27] that combine efforts of local botanists and geneticists from Biotechnology Research Organizations, Botanical Gardens, National Nature Parks and Reserves.

\section{Methods \\ Plant materials}

Two populations of Oxytropis almaatensis, each containing twenty plants per population, were collected in 2015-2016 in two neighboring Gorges of Trans Ili Alatau Mountains. The plant leaves were collected randomly and dried in silica gel. GPS coordinates of two collected populations are given in Table 1.

Big Almaty and Small Almaty Gorges are located in Trans Ili Alatau mountain territory. The approximate locations of populations are shown in Fig. 1. They are growing approximately $10 \mathrm{~km}$ apart.

Trans Ili Alatau mountains is in the northern part of the Tian-Shan mountains system. The North Tian-Shan has a rich and unique flora, different from other regions of Kazakhstan. During the research process, the populations of $O$. almaatensis have been described in geobotanical and floristic aspects according to [28]. The nomenclature of plants was given according to Abdulina [16].

\section{Molecular work}

Total genomic DNA was extracted using a modified CTAB protocol [29], which is detailed in Sramko et al. [30]. The internal transcribed spacers 1 and 2 (ITS) and the 5.8S rRNA gene [31] were PCR amplified. The PCR primers are given in Table 2. The ITS amplification was performed using Veriti Thermo cycler (Applied Biosystems, Foster City, CA, USA). PCR products were verified in $1.5 \%$ agarose gels. Single bands with expected sizes around $650 \mathrm{bp}$ for ITS were cut out from gels and purified using ULTRAPrep ${ }^{\circ}$ Agarose Gel Extraction Mini Prep Kit (AHN Biotechnologie GmbH, Nordhausen, Germany) according to the protocol provided by the company.

Purified DNA amplicons were used for the sequence reactions with forward and reverse primers separately. Ethanol/EDTA method [32] was used in precipitation of products. All reactions were performed with the BigDye Terminator Cycle Sequencing technology (Applied Biosystems, Foster City, CA, USA). Each reaction was carried out in $20 \mu \mathrm{l}$ volume in concentrations described by the company. Sequence analysis was conducted on an ABI 3130 (Applied Biosystems, ThermoFisher Scientific, Waltham, MA, USA) DNA sequencer.

Table 1 Geographical locations of two collected populations of O. almaatensis

\begin{tabular}{lllll}
\hline Populations & Location & Altitude $(\mathrm{m})$ & Coordinates $(\mathrm{N})$ & Coordinates $(\mathrm{E})$ \\
\hline Population 1 & Trans Ili Alatau mountains, Big Almaty gorge & $2158-2160$ & $43^{\circ} 04.864^{\prime}$ & $076^{\circ} 59.604^{\prime}$ \\
Population 2 & Trans Ili Alatau mountains, Small Almaty gorge & $2012-2055$ & $43^{\circ} 08.490^{\prime}$ & $077^{\circ} 04.198^{\prime}$ \\
\hline
\end{tabular}




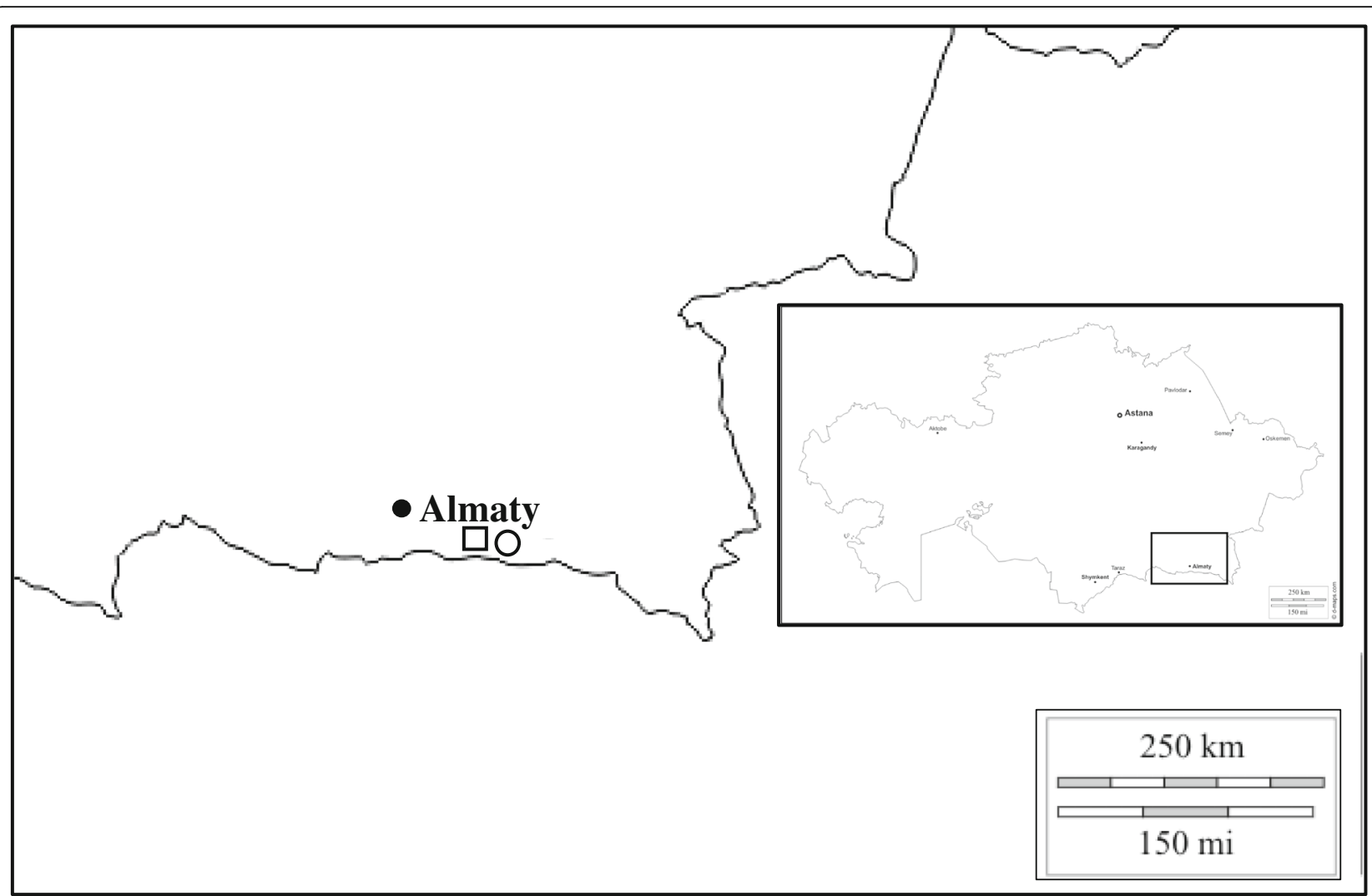

Fig. 1 Geographic locations of two populations of O. almaatensis in the southeast region of Kazakhstan (square - Big Almaty gorge, population 1 , circle - Small Almaty gorge, population 2)

\section{Data analysis}

A phylogenetic analysis was conducted using MaximumLikelihood (ML) [33] in MEGA 5 [34] based on the ITS sequence alignment with 1000 bootstrap replications. The set of sequences included 26 Oxytropis species, including two samples of $O$. almaatensis, 5 samples of $O$. glabra (from NCBI) and two outgroup species Astragalus mongholicus and Caragana dasyphylla (Additional file 1). The names of the sections and subgenera are given according to the Malyshev [1].

\section{Results}

\section{Description of sampling location and morphology of $\mathrm{O}$.}

\section{Almaatensis}

During collecting trips in 2015-2016 two populations of O. almaatensis were found and sampled. Vouchers for herbarium specimens were provided to the department of biodiversity and bioresources of al-Farabi Kazakh National

Table 2 Nucleotide sequences of the ITS primers [31]

\begin{tabular}{lll}
\hline Primers & Primer sequence & Annealing temperature \\
\hline ITS1nF & 5'-AGAAGTCGTAACA & $58^{\circ} \mathrm{C}$ \\
& AGGTTCCGTAGG- 3' 5'- & \\
ITS4nR & TCCTCCGCTTATTGATATGC- 3' & \\
\hline
\end{tabular}

University. Each population consisted of 2 subpopulations and was divided based on differences in floristic composition (see descriptions below). The first population was located at an altitude $2158-2160 \mathrm{~m}$ on the western exposed slope in the spruce zone of the Big Almaty gorge of Trans-Ili Alatau mountains from the river side Kumbelsu. The dominant plant species in floristic composition of subpopulation 1 in decreasing number of plants were Festuca valesiaca, Festuca rubra, Phleum phleoides, Oxytropis almaatensis, Geranium collinum, Thymus marschallianus, Ziziphora interupta, Origanum vulgare, and Achillea millefolium; while in subpopulation 2 they were Aquilegia atrovinosa, Sisymbrium brassiciform, Hypericum perforatum, Oxytropis almaatensis, Elymus tschimganicus, Poa stepposa, Festuca valesiaca, Calamagrostis pavlovii, and Alfredia nivea.

The second population of $O$. almaatensis was found in the Small Almaty Gorge in the Sary-Say tract at an altitude 2012-2055 $\mathrm{m}$ on the slopes of south-west and north-west exposition of the right bank of the river Malaya Almatinka. The composition of the plant communities represented by following dominant plant species for subpopulation 3 in decreasing number of plants were Eremurus robustus, Polygonum soongoricus, Dianthus tianschanicus, Erysimum transilensis, Oxytropis almaatensis, Festuca sulcata, Koeleria gracilis, Poa stepposa, 
Poa nemaralis, and Dactilis glomerata; while for subpopulation 4 those species were Ferula kelleri, Ferula akitschenkensis, Echium italicum, Nepeta panonica, Ziziphora bungeana, Verbascum thapsus, Hypericum perforatum, Festuca sulcata, Poa stepposa, Phleum phleoides, and Dactilis glomerata.

Both populations of $O$. almaatensis were located on screes and on stony gravel deposits along the river and occupied small areas. The status of O. almaatensis populations, based on number of individuals in different age stages, showed that they are in fairly good condition, and there are no immediate threats to their extinction.

The morphological analysis of $O$. almaatensis using plants from the two collected populations, in the same generative adult phase, allowed the assessment of their similarities and differences. Twenty-six plant samples were used for the population 1 and 45 samples for population 2. The morphological analysis was based on several key traits such as plant height, leaf number, leaf length, pair leaflets number, leaflet length, leaflets width, peduncle number, peduncle length, flower number per one peduncle (Table 3). The t-test indicated that both populations were similar for plant height and peduncles number per plant. However, the populations were moderately different for pair leaflet numbers $(P<0.05)$ and peduncle length $(P<0.01)$, and highly different for traits such as leaf number, leaf length, leaflet length and width, and flower number per plant $(P<0.0001)$. In all traits, except in the trait "pair leaflet number", traits in population 1 were larger than in population 2 (Table 3 ) showing the robustness of population 1 plants. Morphological comparison of $O$. almaatensis and O. glabra based on quantification of peduncle length to leaf length ratio confirmed clear differences between the two species. This ratio in $O$. almaatensis was 1.56 versus 1.0 in $O$. glabra (Additional file 2).

\section{Assessment of the phylogenetic position of $O$. almaatensis}

The phylogenetic tree included nrDNA (ITS) sequences of 26 Oxytropis species. A total of five samples of $O$. almaatensis from each populations were sequenced and were found to be identical for their ITS region. Therefore, only one sequence from each population of $O$. almaatensis was utilized in the alignment with 28 additional sequences of Oxytropis species and the outgroup samples of Astragalus and Caragana obtained from GenBank (Additional file 1).

The ML phylogenetic tree for Oxytropis representatives is shown in Fig. 2. The tree shows the relatedness of $O$. almaatensis to $O$. aciphylla, $O$. pilosa and $O$. deflexa, but separated O. almaatensis and O. glabra into a distinct subclade from these species. The aligned length of the ITS region was 601 bp using only
Oxytropis species, but the aligned length increased to 614 bp when the outgroup species (Astragalus mongholicus, Caragana dasyphylla) were included. The number of polymorphic sites without outgroup was 34 or $5.6 \%$ (Table 4). The largest number of polymorphic sites was found in ITS1 (21), followed by ITS2 (11) with only one variable site detected in 5.8RNA (coding) region (Table 4). The ITS sequence analysis in the alignment revealed that three polymorphic sites separate O. almaatensis and O. glabra (Table 4).

\section{Discussion}

In this study, we attempted to clarify the systematic position of $O$. almaatensis, which is a narrow endemic species of the Trans Ili Alatau mountains. Based on botanical descriptions, O. almaatensis was previously classified in section Eumorpha Bunge of subgenera Euoxytropis (Boiss.) Bunge [16]. Later, Malyshev [1] classified this section as part of the subgenus Oxytropis, represented by species that occur in the mountains of Central Asia. Ten samples collected from each of two different populations (10 total samples) of $O$. almaatensis showed no variation in their ITS sequences. The phylogenetic tree based on ITS sequences clearly grouped $O$. almaatensis and O. glabra together (Fig. 2). It should be noted that classical morphological classification placed these taxa in different sections: Eumorpha and Mesogeae, respectively. One of the main differences between these two sections is presence of stems in Mesogea, whereas Eumorpha has stemless species. However, several other traits show high similarities between the two species. The morphological data for $O$. almaatensis (in this study) and literature data for O. glabra [18, 35 indicated that the shape and size of leaves, and paired leaflets are very similar (Additional file 2). In addition, the species share similar habitats in the Tien Shan mountains [18]. The topology of the ML tree suggests that Oxytropis has a monophyletic origin and confirms previous reports with similar results $[10,13$, 14]. The analysis of the polymorphic sites of the ITS showed that 34 out of 614 nucleotides were variable (Table 4) for ITS1, 5.8RNA, and ITS2, and eight polymorphic nucleotides in positions $26,45,67,82,108$, 116, 124 and 426 separated $O$. almaatensis from $O$. glabra. Recently, two papers $[12,26]$ have discussed the level of variability in different DNA barcoding markers for differentiation of medicinal plants. The authors suggested that ITS2 is one of the most appropriate markers in species identification and has a number of advantages over other types of markers, including ITS1. However, results in this study indicated that the number of polymorphic sites in ITS1 was higher (21) than in ITS2 (11) (Table 4). 


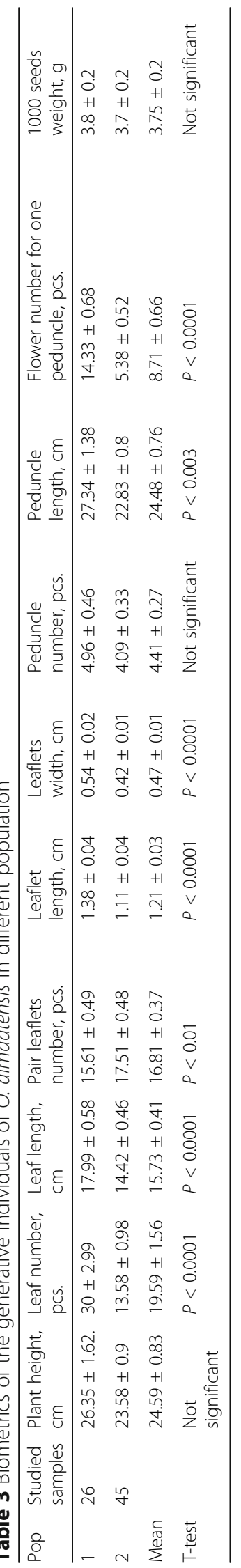




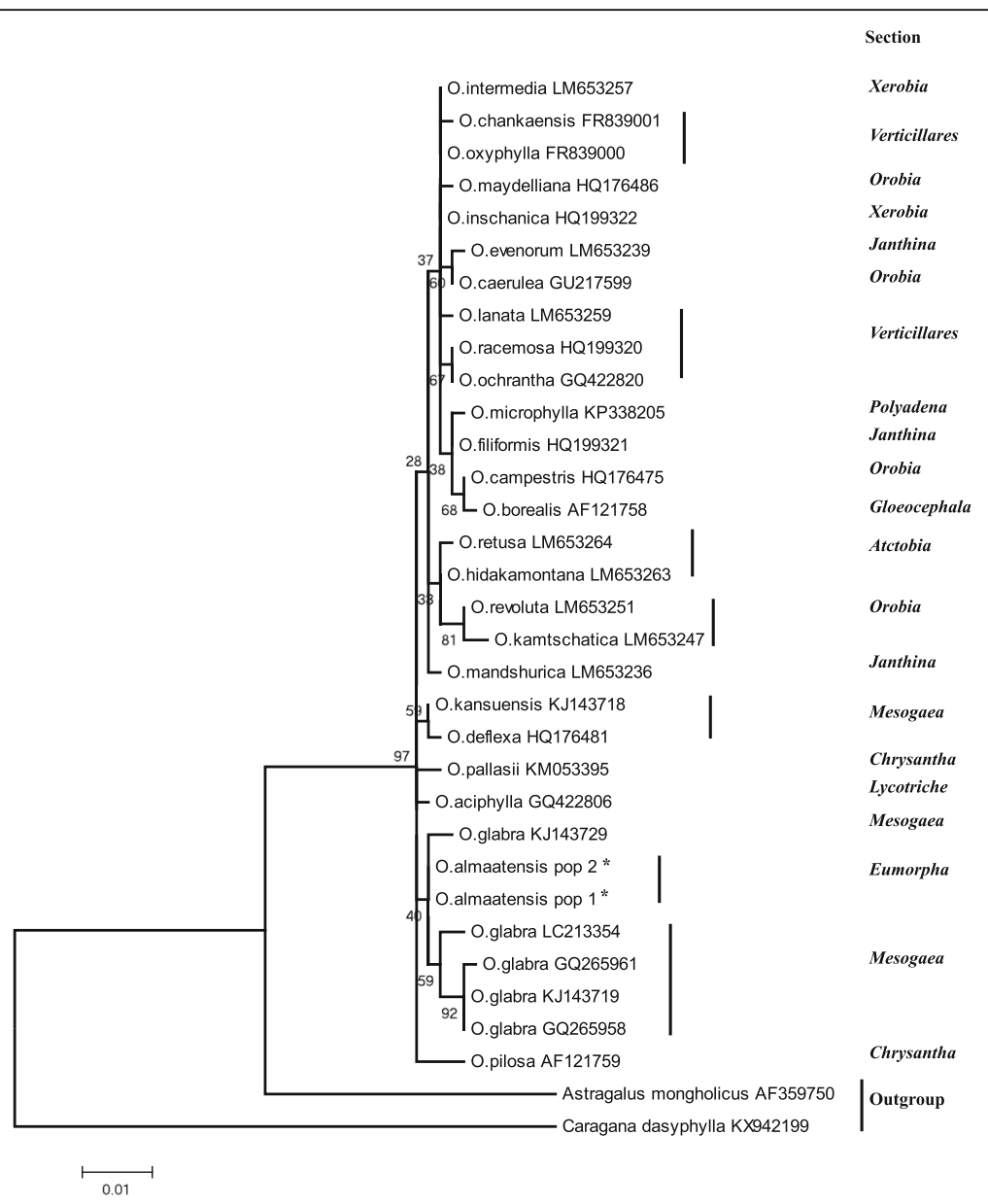

Fig. 2 Phylogenetic tree for Oxytropis species based on ITS sequences using the Maximum Likelihood method. Taxonomical classification is given according to Malyshev [1]. Numbers at nodes show bootstrap values (\%) an * indicates O. almaatensis collected in Kazakhstan. The sequences of Astragalus mongholicus and Caragana dasyphylla are used as a outgroup species

As shown in a number of reports $[8,13,14]$, the taxonomy of Oxytropis is very complicated because of contradictory results for the positioning of species into particular sections and subgenera based on classical botanical studies. The results obtained from the molecular taxonomic studies $[10,13,14]$ were also not congruent because different studies employed different species and different types of DNA markers. Understandably, molecular phylogenetic trees often did not match those proposed by classical morphological studies. The results from the present study is not much different from previously published results in that two species (O. almaatensis and O. glabra), from two different sections, were grouped together in the same subclade. However, many key morphological traits used for the differentiation of sections may rely on single or few genes and may not be associated with analyses of markers from non-coding regions of the genome. Therefore, in order to appreciate the wealth of phenotypic interspecies and intra-specific differences, such as discovered in two populations of $O$. almaatensis, it is critical to apply modern genomic technologies, including next-generation sequencing approaches to a very large and representative set of Oxytropis taxa to infer reliably the taxonomic position of species within the genus.

\section{Conclusions}

The alignment of ITS sequences from samples of two populations of $O$. almaatensis revealed all the sequences were identical. The ML phylogenetic tree based on ITS sequences showed that $O$. almaatensis and O. glabra were separated into a distinct subclade. The topology of the tree confirmed the monophyletic origin of Oxytropis. The analysis of the ITS nucleotide alignment revealed three polymorphic sites between $O$. almaatensis and O. glabra. The variability of ITS1 was higher (21 polymorphic sites) than in the ITS2 region (11). Morphological analysis of individual plants from two populations collected in neighboring 


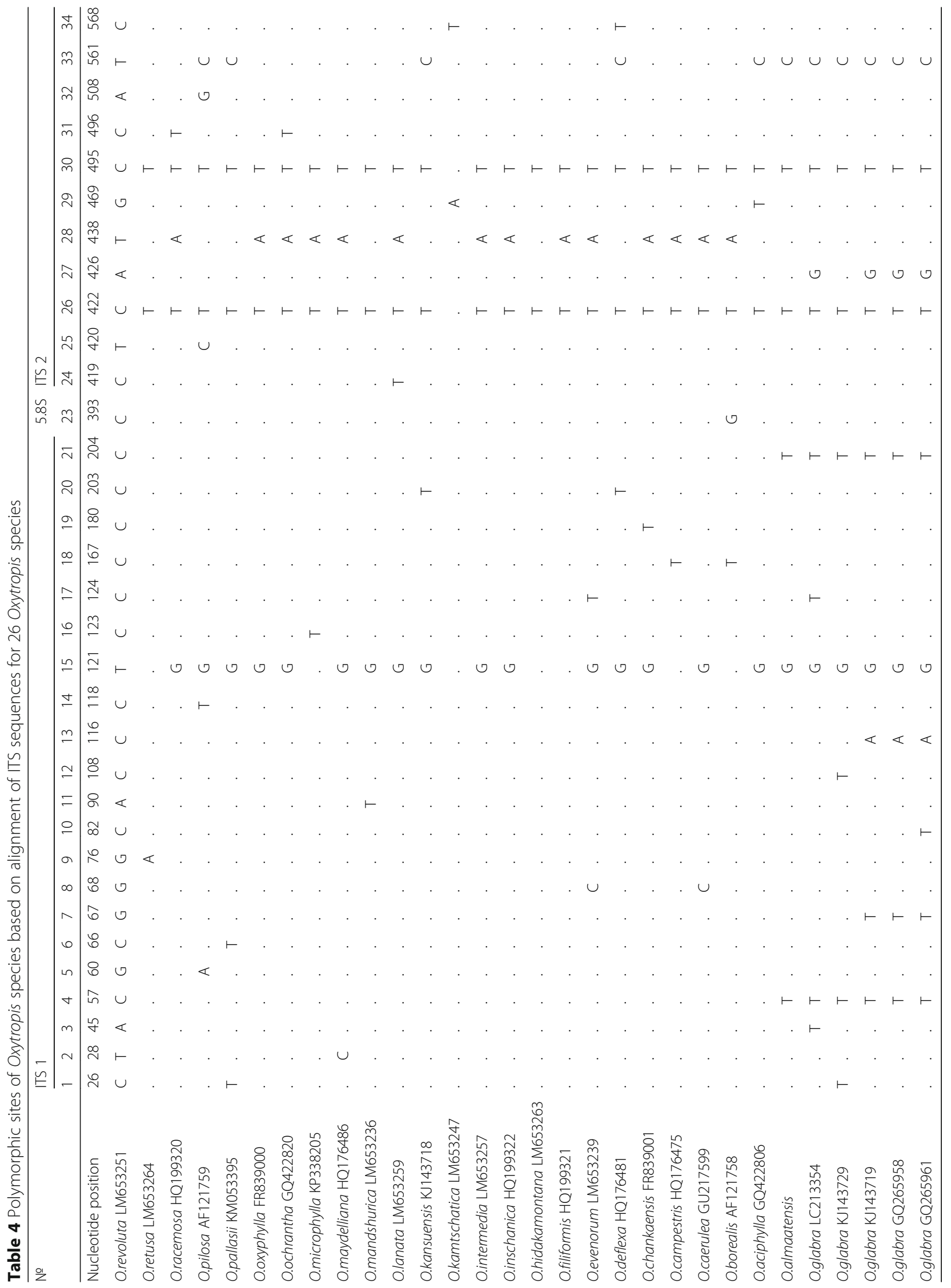


gorges of Trans-Ili Alatau Mountains in Kazakhstan showed a specific pattern in phenotypic variation. The two populations were similar in plant height and peduncles number per plant, but significantly different for traits such as leaf number, leaf length, leaflet length and width, and flower number per plant $(P<0.0001)$.

\section{Additional files}

Additional file 1: Accession number of species obtained from NCBI. (DOCX $15 \mathrm{~kb}$ )

Additional file 2: Comparative morphological description of O.almaatensis and O.glabra. (DOCX $14 \mathrm{~kb}$ )

\section{Acknowledgements}

The authors would like to acknowledge the funding from the Ministry of Education and Sciences of the Republic of Kazakhstan for national program N0237.

\section{Funding}

This publication was funded by special funding allocation within the national program N0237 provided by the Ministry of Education and Sciences of the Republic of Kazakhstan.

\section{Availability of data and materials}

The collecting trips in southeast of Kazakhstan were conducted by scientists at the Institute of Plant Biology and Biotechnology, Almaty, Kazakhstan, which is part of the Ministry of Education and Sciences of the Republic of Kazakhstan. The permission for collecting trip in designated area was given by the Committee of Forest and Animal World at the Ministry of Agriculture (issued N18-02-32/1579-CFAW from 10.04.2015).

\section{About this supplement}

This article has been published as part of BMC Plant Biology Volume 17 Supplement 1, 2017: Selected articles from PlantGen 2017. The full contents of the supplement are available online at https://bmcplantbiol.biomedcentral.com/ articles/supplements/volume-17-supplement-1.

\section{Authors' contributions}

SAb and NM carried out the experimental design. SAI collected $O$. almaatensis species, performed morphological descriptions and developed herbarium specimens. SAb and SAI carried out the DNA extraction, DNA sequencing and the alignment of the $O$. almaatensis sequences. SAb and SAI participated in preparation of the manuscript. All authors reviewed the draft of the manuscript. All authors read and approved the final manuscript.

\section{Ethics approval and consent to participate}

Not applicable

\section{Consent for publication}

Not applicable

\section{Competing interests}

The authors declare they have no competing interests.

\section{Publisher's Note}

Springer Nature remains neutral with regard to jurisdictional claims in published maps and institutional affiliations.

\section{Published: 14 November 2017}

\section{References}

1. Malyshev LI. Phenetics of the subgenera and sections in the genus Oxytropis DC. (Fabaceae) bearing on ecology and phylogeny. Contemp Probl Ecol. 2008;1(4):440-4.
2. Grubov VI. In: Grubov VL, editor. Plants of Central Asia - plant collection from China and Mongolia. Vol. 8b: legumes, genus: Oxytropis. Enfield: Taylor \& Francis; 2003.

3. Polhill RM. In: Polhill RM, Raven PH, editors. Galegeae. Surrey, UK: Advances in legume systematics, part 1. Royal Botanic Gardens, Kew, Richmond; 1981. p. 357-363.

4. Erkula SK, Celepb F, Aytaç Z. Seed morphology and its systematic implications for genus Oxytropis DC. (Fabaceae). Plant Biosyst. 2014;149:875-83.

5. Zhang ML, Podlech D. Revision of the genus Phyllolobium Fisch. (Leguminosae-Papilionoideae). Feddes Repertorium. 2006;117:41-64.

6. Chaudhary LB, Rana TS, Anand KK. Current status of the systematics of Astragalus L. (Fabaceae) with special reference to the Himalayan species in India. Taiwania. 2008:53(4):338-55.

7. Wojciechowski MF. Astragalus (Fabaceae): a molecular phylogenetic perspective. Brittonia. 2005:57:382-96.

8. Abdulina SA. Oxytropes of northern Tien Shan (structure, botanicalgeographical communications). Almaty: Dissertation abstract; 1984. 20 p.

9. Tekpinar A, Erkul SK, Aytac Z, Kaya Z. Phylogenetic relationships among native Oxytropis species in Turkey using the trnL intron, trnL-F IGS, and trnV intron cpDNA regions. Turk J Bot. 2016;40(5):472-9.

10. Kholina AB, Kozyrenko MM, Artyukova EV, Sandanov DV, Andrianova EA Phylogenetic relationships of the species of Oxytropis DC. Subg. Oxytropis and Phacoxytropis (Fabaceae) from Asian Russia inferred from the nucleotide sequence analysis of the intergenic spacers of the chloroplast genome. Russ J Genet. 2016;52(8):780-93.

11. Malyshev L. Diversity of the genus Oxytropis in Asian Russia. Turczaninowia. 2008;11(4):5-141

12. Gao J, Lu P, Wang J, Jin F, Enhe B. Molecular phylogeny of several species of Oxytropis DC. Based on 5.8SrDNA/ITS sequence. Acta Agriculturae BorealiSin. 2009:24(6):168-73.

13. Artyukova EV, Kozyrenko MM. Phylogenetic relationships of Oxytropis chankaensis Jurtz. And Oxytropis oxyphylla (pall.) DC. (Fabaceae) inferred from the data of sequencing of the ITS region of the nuclear ribosomal DNA operon and intergenic spacers of the chloroplast genome. Genetika. 2012;48:186-93.

14. Jorgensen JL, Stehlik I, Brochmann C, Conti E. Implications of ITS sequences and RAPD markers for the taxonomy and biogeography of the Oxytropis campestris and O. arctica (Fabaceae) complexes in Alaska. Am J Bot. 2003: 90(10):1470-80.

15. Archambault A, Strömvik MV. Evolutionary relationships in Oxytropis species, as estimated from the nuclear ribosomal internal transcribed spacer (ITS) sequences point to multiple expansions into the Arctic. Botany. 2012;90:770-9.

16. Abdulina SA. Checklist of vascular plants of Kazakhstan. Ed. by Kamelin RV. Almaty: Academy of Sciences of Kazakhstan; 1998. 187 p.

17. The Red book of Kazakhstan. The 2nd edition revised and supplemented. Volume 2. In. Baitulin IO, editor. Astana: LTD «ArtPrintXX|»; 2014. 452 p.

18. Baitenov MS, Vasilyeva AN, Gamayunova AP, Goloskokov VP, Orazova A, Roldugin II, et al. In: Pavlov NV, editor. Flora Kazakhstana. Alma-Ata; 1961. 493 p.

19. Grudzinskaya LM, Gemedzhieva NG, Nelina NV, Karzhaubekova JJ. Annotated checklist of medicinal plants in Kazakhstan: a reference book. Almaty: Institute of botany and phytointroduction; 2014

20. Turuspekov Y, Abugalieva S, Ermekbayev K, Sato K. Genetic characterization of wild barley populations (Hordeum vulgare Ssp. spontaneum) from Kazakhstan based on genome wide SNP analysis. Breed Sci. 2014;64(4):399-403.

21. Adams RP, Turuspekov Y. Taxonomic reassessment of some central Asian and Himalayan scale-leaved taxa of Juniperus (Cupressaceae) supported by random amplification of polymorphic DNA. Taxon. 1998:47:75-84.

22. Turuspekov Y, Adams RP, Kearney CM. Genetic diversity in three perennial grasses from the Semipalatinsk nuclear testing region of Kazakhstan after long-term radiation exposure. Biochem Syst Ecol. 2002;30(9):809-17.

23. Alvarez I, Wendel JF. Ribosomal ITS sequences and plant phylogenetic inference. Mol Phylogenet Evol. 2003;29(3):417-34.

24. Kress WJ, Wurdack KJ, Zimmer EA, Weigt LA, Janzen DH. Use of DNA barcodes to identify flowering plants. Proc Natl Acad Sci U S A. 2005; 102(23):8369-74

25. Gültepe M, Uzuner U, Coșkunçelebi K, Beldüz AO, Terzioğlu S. Internal transcribed spacer (ITS) polymorphism in the wild Primula (Primulaceae) taxa of Turkey. Turk J Bot. 2010;34(3):147-57.

26. Cheng T, Xu C, Lei L, Li C, Zhang Y, Zhou S. Barcoding the kingdom Plantae: new PCR primers for ITS regions of plants with improved universality and specificity. Mol Ecol Resour. 2016;16(1):138-49. 
27. Turuspekov Y, Abugalieva S. Plant DNA barcoding project in Kazakhstan. Genome. 2015;58(5):290.

28. Lavrenko EM, Korchagin AA. In: Lavrenko EM, Korchagin AA, editors. Field geobotany. Moscow-Leningrad: Publishing House of the USSR Academy; 1976.

29. Doyle JJ, Doyle JL. A rapid DNA isolation procedure for small quantities of fresh leaf tissue. Phytochemistry Bull. 1987;19:11-5.

30. Sramko G, Attila MV, Hawkins JA, Bateman RM. Molecular phylogeny and evolutionary history of the Eurasiatic orchid genus Himantoglossum S.L. (Orchidaceae). Ann Bot. 2014;114(8):1609-26.

31. White TJ, Bruns T, Lee S, Taylor JW. In: PCR Protocols: A Guide to Methods and Applications, Innis MA, Gelfand DH, Sninsky JJ, White TJ, editors. Amplification and direct sequencing of fungal ribosomal RNA genes for phylogenetics. Academic Press, Inc. New York; 1990.

32. Zeugin JA, Hartley JL. Ethanol precipitation of DNA. Focus. 1985;7(4):1-2.

33. Tamura $\mathrm{K}$, Nei M. Estimation of the number of nucleotide substitutions in the control region of mitochondrial DNA in humans and chimpanzees. Mol Biol Evol. 1993;10(3):512-26.

34. Tamura K, Peterson D, Peterson N, Stecher G, Nei M, Kumar S. MEGA5: molecular evolutionary genetics analysis using maximum likelihood, evolutionary distance, and maximum parsimony methods. Mol Biol Evol. 2011;28(10):2731-9.

35. efloras. Missouri Botanical Garden, St. Louis, MO \& Harvard University Herbaria, Cambridge, MA. 2008. http://www.efloras.org. Accessed 04 July 2017.

\section{Submit your next manuscript to BioMed Central} and we will help you at every step:

- We accept pre-submission inquiries

- Our selector tool helps you to find the most relevant journal

- We provide round the clock customer support

- Convenient online submission

- Thorough peer review

- Inclusion in PubMed and all major indexing services

- Maximum visibility for your research

Submit your manuscript at www.biomedcentral.com/submit 